Original Article

\title{
Chylomicron Remnants Stimulate Release of Interleukin-1 $\beta$ by THP-1 Cells
}

\author{
Takahiro Okumura ${ }^{1}$, Yoshio Fujioka ${ }^{1,4}$, Shinji Morimoto², Miho Masai ${ }^{1}$, Tsuyoshi Sakoda ${ }^{1}$, \\ Takeshi Tsujino², Shin-ichiro Kashiwamura ${ }^{3}$, Haruki Okamura ${ }^{3}$, and Mitsumasa Ohyanagi ${ }^{1}$ \\ ${ }^{1}$ Department of Internal Medicine, Division of Coronary Heart Disease, Hyogo College of Medicine, Nishinomiya, \\ Japan. \\ ${ }^{2}$ Department of Internal Medicine, Cardiovascular Division, Hyogo College of Medicine, Nishinomiya, Japan. \\ ${ }^{3}$ Laboratory of Host Defenses, Institute for Advanced Medical Sciences, Hyogo College of Medicine, Nishinomiya, \\ Japan. \\ ${ }^{4}$ Present address; Division of Cardiovascular and Respiratory Medicine, Department of Internal Medicine, Kobe \\ University of Graduate School of Medicine, Kobe, Japan.
}

\begin{abstract}
Recent findings suggest that the oxidative modification of low-density lipoproteins (LDL) and an increase in triglyceride-rich lipoprotein particles including chylomicron remnants contribute to the progression of atherosclerosis, as does the inflammatory response. We therefore examined whether and how these lipoproteins affected interleukin (IL)-1 $\beta$ release and mRNA expression for IL-1 $\beta$ and IL-18 in THP-1 cells, a human monocyte cell line. Chylomicron remnants increased IL-1 $\beta$ release into the conditioned medium by THP-1 in a dose- and time-dependent manner. At concentrations up to $1 \mu \mathrm{g} / \mathrm{ml}$, chylomicron remnants increased IL-1 $\beta$ release by 4 -fold compared with the control. Neither native LDL nor oxidized LDL (OxLDL) significantly increased IL-1 $\beta$ release. Chylomicron remnants increased IL-1 $\beta$ mRNA expression by 3 times. Native LDL or OxLDL did not increase IL-1 $\beta$ mRNA, while neither these lipoproteins nor chylomicron remnants increased IL-18 mRNA. Chylomicron remnants also increased the activities of caspase-1 and nuclear factor (NF)- $\mathrm{kB}$ significantly, while native LDL or OxLDL did not. In conclusion, chylomicron remnants stimulated IL-1 $\beta$ mRNA expression and IL-1 $\beta$ protein production probably via caspase-1 and NF-KB activation in THP-1 cells. J Atheroscler Thromb, 2006; 13: 38-45.
\end{abstract}

Key words: Chylomicron remnants, Interleukin-1 $\beta$, Interleukin-18, Macrophages

\section{Introduction}

Hyperlipidemia is one of the most important risk factors for atherosclerosis. The biologic mechanisms by which lipids induce the vascular inflammation, cellular proliferation, lipid deposition, and fibrosis that characterize atherosclerosis remain largely unknown, but recent findings suggest that oxidative modification of low-density lipoproteins (LDL) is a key contributor to the pro-

Address for correspondence: Yoshio Fujioka, Division of Cardiovascular and Respiratory Medicine, Department of Internal Medicine, Kobe University Graduate School of Medicine, 7-5-2, Kusunoki-cho, Chuo-ku, Kobe 650-0017, Japan.

E-mail: fujiokay@med.kobe-u.ac.jp

Received August 25, 2005

Accepted for publication October 18, 2005 gression of atherosclerosis $(1,2)$. On the other hand, triglyceride-rich lipoprotein particles including chylomicron remnants are also atherogenic (3-12). Chylomicron remnants are derived from chylomicrons through lipoprotein lipase-mediated hydrolysis of triglycerides in these particles. In normal subjects, chylomicron remnants persist only transiently in the plasma during the postprandial period, as they are removed rapidly from the systemic circulation. However, delayed clearance of these triglyceride-rich lipoprotein particles often occurs in certain genetic or metabolic disorders characterized clinically as showing mixed hyperlipidemia. Accumulating evidence indicates an association between delay in remnant lipoprotein clearance and increased risk of cardiovascular diseases $(4,13,14)$. Monocyte/macrophages are thought to participate in the formation of the atherosclerotic le- 
sion, particularly its earliest identifiable form, the fatty streak. This lesion is characterized by the presence of lipid-laden cells termed foam cells, derived mainly from macrophages. Moreover, monocyte/macrophages participate in the inflammatory response $(1,2)$. Interleukin (IL)-1 $\beta$, a potent mediator of inflammation and the immune response, is produced primarily by activated monocytes. Stimulation of monocytes by lipopolysaccharide (LPS), phorbol 12-myristate acetate (PMA), or IL-1 $\beta$ itself leads to IL-1 $\beta$ production via activation of the IL-1 $\beta$ gene, leading to expression of IL-1 $\beta$ mRNA and translation of pro-IL-1 $\beta$ (6), which is processed to mature IL-1 $\beta$ by caspase-1 (previously termed IL-1 converting enzyme) $(16,17)$. Several recently reported lines of evidence suggest that IL-1 $\beta$ is proatherogenic $(1,2)$. To elucidate the roles of atherogenic lipoproteins including oxidatively modified LDL (OxLDL) and chylomicron remnants in the development of atherosclerosis, we studied IL-1 $\beta$ release in a human monocyte cell line, THP-1, in response to stimulation by these lipoproteins. IL-18, a member of the IL-1 cytokine family, was identified originally in macrophages and Kupffer cells as a factor able to stimulate production of an interferon $\gamma$-inducing factor by $\mathrm{T}$ cells (18, 19). Recently, it was reported that IL-18 is also associated with the formation of atherosclerotic lesions (2023). We also examined the expression of IL-18 mRNA by THP-1 cells in response to stimulation by native LDL, OxLDL, or chylomicron remnants.

\section{Materials and Methods}

\section{Materials}

RPMI 1640 medium and a penicillin-streptomycin mixture were purchased from GIBCO Laboratories (Grand Island, NY). Fetal bovine serum (FBS), lipoprotein-deficient serum (LPDS), and phorbol 12-myristate 13-acetate (PMA) were obtained from Sigma Chemical (St. Louis, MO). We obtained $\left[\alpha{ }^{-32 P}\right] d C T P$ and $\left[\gamma^{-32 P}\right]$ ATP from Amersham Biosciences (Piscataway, NJ). Male SpragueDawley rats were purchased from Japan SLC (Hamamatsu, Japan) for use in the preparation of chylomicrons and chylomicron remnants. The animals had free access to food and water. All other chemicals and materials were obtained from Wako (Osaka, Japan).

\section{Lipoproteins}

Chylomicrons and chylomicron remnants were separated from rat mesenteric lymph as previously described $(5-8,24)$. Briefly, chylomicrons were isolated by ultracentrifugation from lymph collected from gastrostomized male Sprague-Dawley rats fed an egg suspension for 48 $\mathrm{h}$. These functionally hepatectomized rats then were injected intravenously with the chylomicrons, and finally exsanguinated after $3 \mathrm{~h}$. Chylomicron remnants were isolated from the plasma by ultracentrifugation. To deter- mine whether chylomicron remnants were successfully prepared, selected preparations of chylomicrons and chylomicron remnants were analyzed as to their lipid composition, as previously described $(5-8,24)$. Ratios of triglyceride to total cholesterol (w/w) were 76.9 in chylomicrons and 4.5 in chylomicron remnants $(n=5)$. The apolipoprotein content of chylomicron remnants was analyzed by sodium dodecyl sulfate-polyacrylamide gel electrophoresis on 3 to $15 \%$ gradient gels; the apolipoprotein (apo) E content was far greater in chylomicron remnants than in chylomicrons. We also confirmed a previously described increase in the percentage of lysophosphatidylcholine (LPC) among phospholipids extracted from chylomicron remnants beyond the percentage found in chylomicrons $(7.6 \%$ vs. $0.3 \%, n=5)$. These data showed that isolated chylomicron remnants had characteristics of chylomicron remnants as apoE-and LPC-enriched particles as previously described $(24,25)$. Human native LDL and Ox LDL were prepared by established methods (26). Briefly, LDL ( $d=1.019-1.050 \mathrm{~g} / \mathrm{ml})$ were obtained by centrifugation of venous blood samples, followed by ultracentrifugation and dialysis against phosphate-buffered saline (PBS) without chelating agents. LDL were oxidized by incubating $2 \mathrm{mg} / \mathrm{ml} \mathrm{LDL}$ in $5 \mu \mathrm{mol} / / \mathrm{CuSO}_{4}$ in PBS at $37^{\circ} \mathrm{C}$ for $16 \mathrm{~h}$; oxidation was confirmed by agarose gel electrophoresis. Bacterial lipopolysaccharide was not detected in any of the lipoprotein preparations. All experiments were performed in accordance with a protocol approved by the Guidelines for Animal Experimentation and Hospital Ethics Committee at Hyogo College of Medicine. All volunteers gave informed consent.

\section{Cells}

A human monocytic leukemia cell line, THP-1, was obtained from the American Type Culture Collection (ATCC, Manassas, VA). Cells were seeded at $10^{6}$ cells/well in 24-well tissue culture plates (Nunc, Roskilde, Denmark) or $5.0 \times 10^{6}$ cells/dish in $60-\mathrm{mm}$ tissue culture dishes (Falcon; Becton Dickinson, Oxnard, CA) in RPMI1640 medium supplemented with penicillin (100 units $/ \mathrm{ml}$ ), streptomycin $(100 \mu \mathrm{g} / \mathrm{ml})$, L-glutamine $(292 \mu \mathrm{g} / \mathrm{ml})$, and $10 \%$ FBS. Incubation proceeded in a humidified atmosphere of $95 \%$ air and $5 \% \mathrm{CO}_{2}$. After differentiation was induced with $100 \mathrm{nmol} / \mathrm{PMA}$ in RPMI-1640 medium with $10 \%$ LPDS for $48 \mathrm{~h}(5)$, cells were incubated with various lipoproteins in RPMI-1640 medium without FBS. Cell viability was assessed using the cell proliferation reagent WST-1 (Boeringher Manheim, Wilmington, DE). Incubation medium with or without lipoproteins in the concentrations used in this study did not affect the viability of THP-1 cells, as determined by the WST-1 assay (data not shown). Caco-2 cells (a human colon adenocarcinoma cell line; ATCC) maintained in RPMI-1640 medium with penicillin (100 units $/ \mathrm{ml})$, streptomycin $(100 \mu \mathrm{g} / \mathrm{ml})$, L-glutamine $(292 \mu \mathrm{g} / \mathrm{ml})$, and $10 \%$ FBS were used in 
Northern blot analyses as a standard for IL-18 (27).

\section{Analysis of secreted IL-1 $\beta$}

Concentrations of IL-1 $\beta$ in culture supernatants were determined by a commercial enzyme immunoassay (EIA; Cayman, Ann Arbor, MI) according to the manufacturer's instructions.

\section{Northern blot analysis}

THP- 1 cells $\left(5.0 \times 10^{6}\right)$ in $6-\mathrm{cm}$ dishes were incubated in control medium in the presence or absence of 0.1 to $1.0 \mu \mathrm{g} / \mathrm{ml}$ chylomicron remnants for 6 to $24 \mathrm{~h}$. Total RNA was extracted using TRIzol reagent (modified acid guanidium thiocyanate phenol/chloroform method; Invitrogen, Carlsbad, CA) according to the manufacturer's instructions. Northern blot analyses of IL-1 $\beta, \mathrm{IL}-18$, and glyceraldehyde-3-phosphate dehydrogenase (GAPDH) were performed as previously described (24). Human IL$1 \beta$ and IL-18 cDNAs were obtained from R\&D Systems (Minneapolis, MN) and used as previously described (18). All other chemicals and materials were obtained from Wako (Osaka, Japan). Relative intensities of bands identified were determined using a BAS 2000 phosphor imager (Fuji Photo Film, Tokyo, Japan) and were normalized to that of GAPDH, and expressed as a percentage relative to the value obtained before incubation.

\section{Assay of caspase-1 activity}

Activity of caspase- 1 was detected with a caspase- 1 fluorometric protease assay kit (Chemicon International, Temecula, CA). Aliquots of cell lysates were diluted in reaction buffer containing $50 \mu \mathrm{mol} / \mathrm{l}$ Ac-Tyr-Val-Ala-Asp7-amino-4-methylcoumarin and then incubated for $90 \mathrm{~min}$ at $37^{\circ} \mathrm{C}$. The release of 7 -amino-4-methylcoumarin was detected by luminescence spectrometry with excitation of $390 \mathrm{~nm}$ for an emission at $510 \mathrm{~nm}$.

\section{Electromobility shift assay}

To determine the mechanism underlying chylomicron remnant-induced transcription, we prepared nuclear extracts from $5.0 \times 10^{6} \mathrm{THP}-1$ cells after stimulation with lipoproteins for 6 or $24 \mathrm{~h}$, and monitored the extracts with an electromobility shift assay (EMSA) as previously described (7). For detection of nuclear factor (NF)- $\kappa B$ activation, we used a NUSHIFT KIT [NFkB p65 (HUMAN)] (Geneka Biotechnology, Montréal, Canada) according to the manufacturer's protocol. Specificity of binding was determined with an anti-p65 antibody against NF-кB.

\section{Protein assay}

Protein was measured by the method of Lowry et al. (28) or by the Pierce BCA protein assay method (Pierce; Rockford, IL), using bovine serum albumin (BSA) as the standard.

\section{Statistical analysis}

Data are expressed as the mean \pm SEM. Analysis of variance (ANOVA) with Scheffé's test was performed using an Apple Macintosh computer with Statview software (Abacus Concepts, Cary, NC). Two-tailed values of $p<0.05$ were considered to indicate statistical significance.

\section{Results}

\section{IL-1 $\beta$ release in THP-1 cells stimulated by lipo- proteins}

Chylomicron remnants increased IL-1 $\beta$ release by THP1 cells into the conditioned medium in a time- and dosedependent manner (Fig. 1A, B). The presence of chylomicron remnants of concentrations up to $1 \mu \mathrm{g} / \mathrm{ml}$ for 24 $\mathrm{h}$ stimulated IL-1 $\beta$ release 4 times greater than in controls $(0 \mathrm{~h})$. Smaller increases in IL-1 $1 \beta$ release were observed with incubation using native LDL or OxLDL.

\section{Expression of IL-1 $\beta$ mRNA in THP-1 cells stimu- lated by lipoproteins}

Expression of IL-1 $\beta$ mRNA after incubation with chylomicron remnants at $1 \mu \mathrm{g} / \mathrm{ml}$ for $24 \mathrm{~h}$ was 3 times greater than in controls (Fig. 2A, B). Native LDL and OxLDL did not significantly increase IL-1 $\beta$ mRNA.

\section{Expression of IL-18 mRNA in THP-1 cells stimu- lated by lipoproteins}

When we also examined expression of IL-18 mRNA after incubation with native LDL, OxLDL, or chylomicron remnants. None of these lipoproteins stimulated the mRNA expression (Fig. 3).

\section{Caspase-1 activity in THP-1 cells stimulated by lipoproteins}

Next we examined whether chylomicron remnants could affect caspase- 1 activity in THP-1 cells. Activity of caspase-1 was up-regulated significantly by stimulation with chylomicron remnants (Fig. 4).

\section{NF- $\kappa B$ activation in THP-1 cells stimulated by lipoproteins}

Activity of the transcription factor, NF- $\kappa \mathrm{B}$, was analyzed using EMSA. In THP-1 cells, chylomicron remnants activated NF- $\kappa B$ significantly (Fig $5 A$, B). Specificity was evaluated by supershift analysis with a specific antibody against the $\mathrm{p} 65$ subunit of NF-KB. Neither native LDL nor OxLDL significantly increased NF- $\mathrm{KB}$ binding activity.

\section{Discussion}

Several recent studies considering the involvement of chylomicron remnants in the pathogenesis of atherosclerosis have identified a delay in their removal from serum 
A

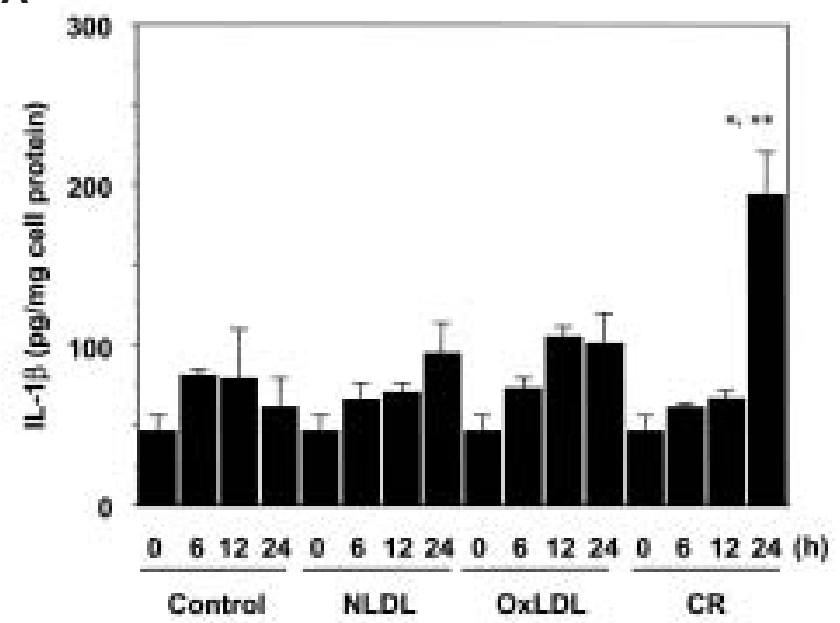

B

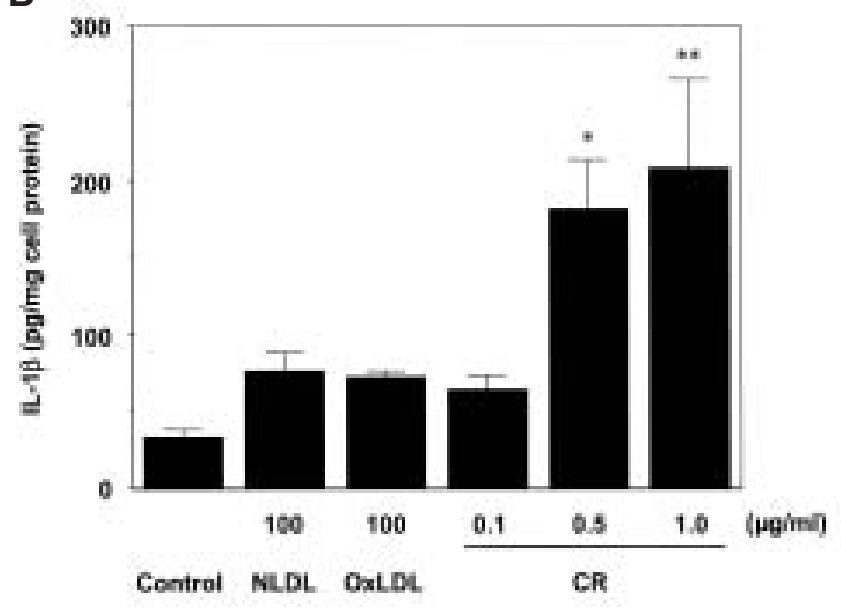

Fig. 1. Effects of native LDL (NLDL), oxidized LDL (OxLDL), and chylomicron remnants (CR) on interleukin (IL)-1 $\beta$ release. A: After differentiation as described in Materials and Methods, cells were incubated with $100 \mu \mathrm{g} / \mathrm{ml} \mathrm{NLDL,} 100 \mu \mathrm{g} / \mathrm{ml} \mathrm{OxLDL}$, or $0.5 \mu \mathrm{g} / \mathrm{ml}$ CR in RPMI-1640 medium without FBS for the periods indicated. IL-1 $\beta$ protein concentrations in the conditioned medium were assayed by EIA. Values are the mean \pm SEM for four independent experiments. $*, p<0.005$ vs. control $(0 \mathrm{~h}) ; * *, p<0.01 \mathrm{vs}$. $6 \mathrm{~h}$ or $12 \mathrm{~h}$ of CR stimulation by ANOVA with Scheffé's test. B: After differentiation, cells were stimulated with $100 \mu \mathrm{g} / \mathrm{ml} \mathrm{NLDL}, 100 \mu \mathrm{g} / \mathrm{ml}$ OxLDL, or indicated concentrations of CR in RPMI-1640 medium without FBS for $24 \mathrm{~h}$. Concentrations of IL-1 $\beta$ protein were assayed by EIA. In four independent experiments, *, $p<0.05 ; * *, p<0.005$ vs. control by ANOVA with Scheffé's test.

A

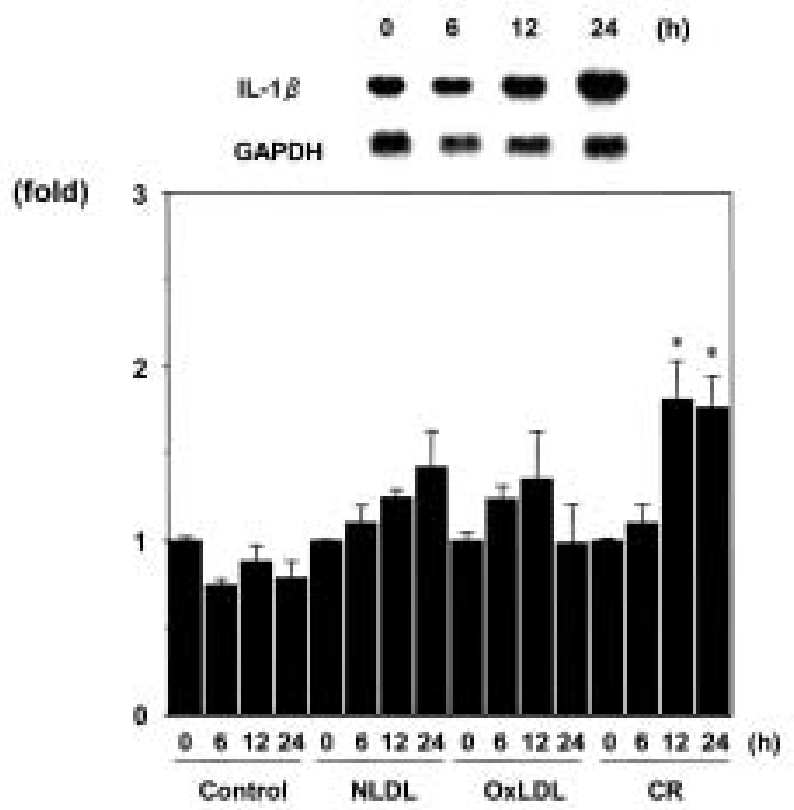

B

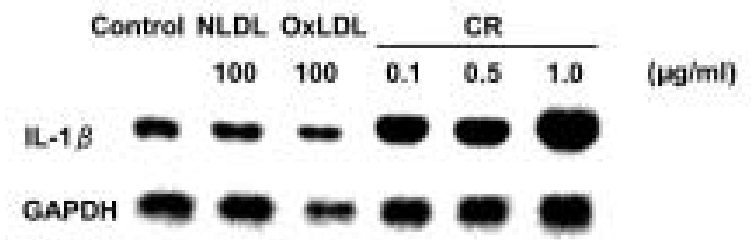

(fold)

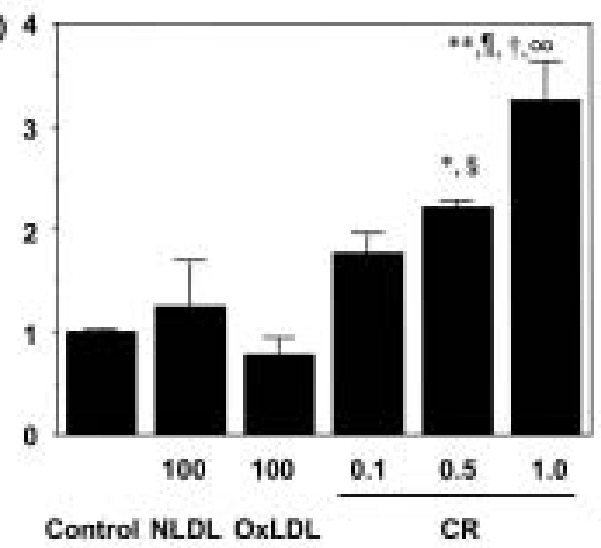

(Mgiml)

Fig. 2. Effects of NLDL, OxLDL, and CR on IL-1 $\beta$ mRNA expression. A: After differentiation, cells were incubated with no lipoprotein (control), $100 \mu \mathrm{g} / \mathrm{ml} \mathrm{NLDL}, 100 \mu \mathrm{g} / \mathrm{ml}$ OxLDL, or $0.5 \mu \mathrm{g} / \mathrm{ml}$ CR in RPMI-1640 medium without FBS for the periods indicated. Expression of IL-1 $\beta$ mRNA and GAPDH mRNA was determined by Northern blot analysis. In four separate experiments, *, $p<0.05$ vs. the value before incubation $(0 \mathrm{~h})$ by ANOVA with Scheffé's test. Upper panel shows that IL-1 $\beta$ mRNA expression stimulated by CR for periods indicated. Lower panel shows fold increases after stimulation by NLDL, OxLDL or CR. B: After differentiation, cells were stimulated with $100 \mu \mathrm{g} / \mathrm{ml}$ NLDL, $100 \mu \mathrm{g} / \mathrm{ml}$ OxLDL, or indicated concentrations of CR in RPMl-1640 medium without FBS for $24 \mathrm{~h}$. In four separate experiments, *, $p<0.05 ; * *, p<0.001$; vs. control; $\S, p<0.005$ vs. OxLDL; $\uparrow, p<0.001$ vs. NLDL; †, $p<0.001$ vs. OxLDL; $\infty, p<0.01$ vs. $0.1 \mu \mathrm{g} / \mathrm{ml}$ CR by ANOVA with Scheffé's test. 


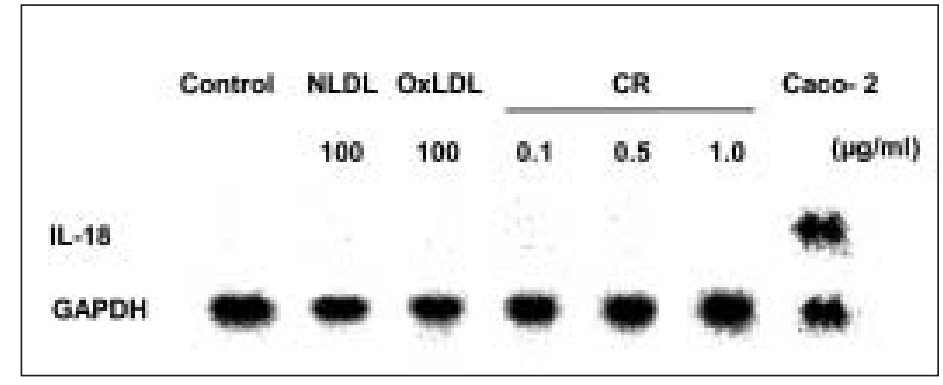

Fig. 3. Effects of NLDL, OxLDL, and CR on IL-18 mRNA expression. Differentiated cells were seeded and stimulated with no lipoprotein (control), $100 \mu \mathrm{g} / \mathrm{ml} \mathrm{NLDL,} 100 \mu \mathrm{g} / \mathrm{ml}$ OxLDL, or $0.1,0.5$, or $1.0 \mu \mathrm{g} /$ $\mathrm{ml}$ CR in RPMl-1640 medium without FBS for $24 \mathrm{~h}$. Expression of IL18 mRNA and GAPDH mRNA were determined by Northern blot analysis. Caco-2 cells were used as a positive control.

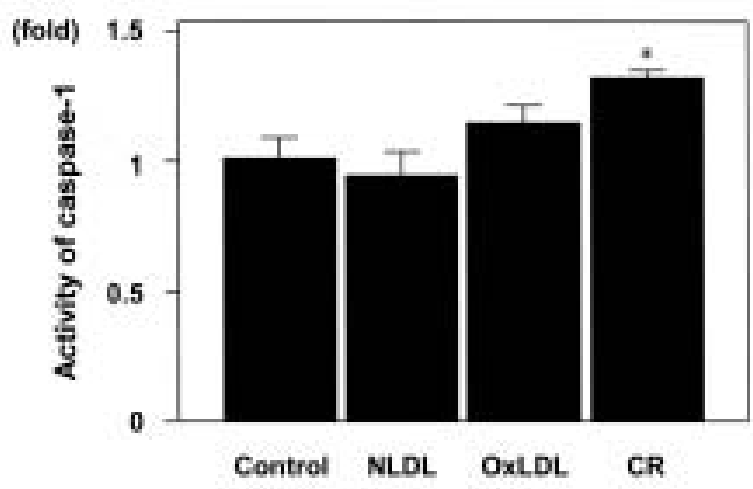

Fig. 4. Effects of NLDL, OxLDL, and CR on caspase-1 activity. Lysates were prepared from $5.0 \times 10^{6} \mathrm{THP}-1$ cells. Activity of caspase-1 was detected fluorometrically by luminescence spectrometry. Activity (the mean \pm SEM for four independent experiments) is expressed as a percentage relative to the value obtained with the control. *, $p<0.05$ vs. control by ANOVA with Scheffé's test.

A

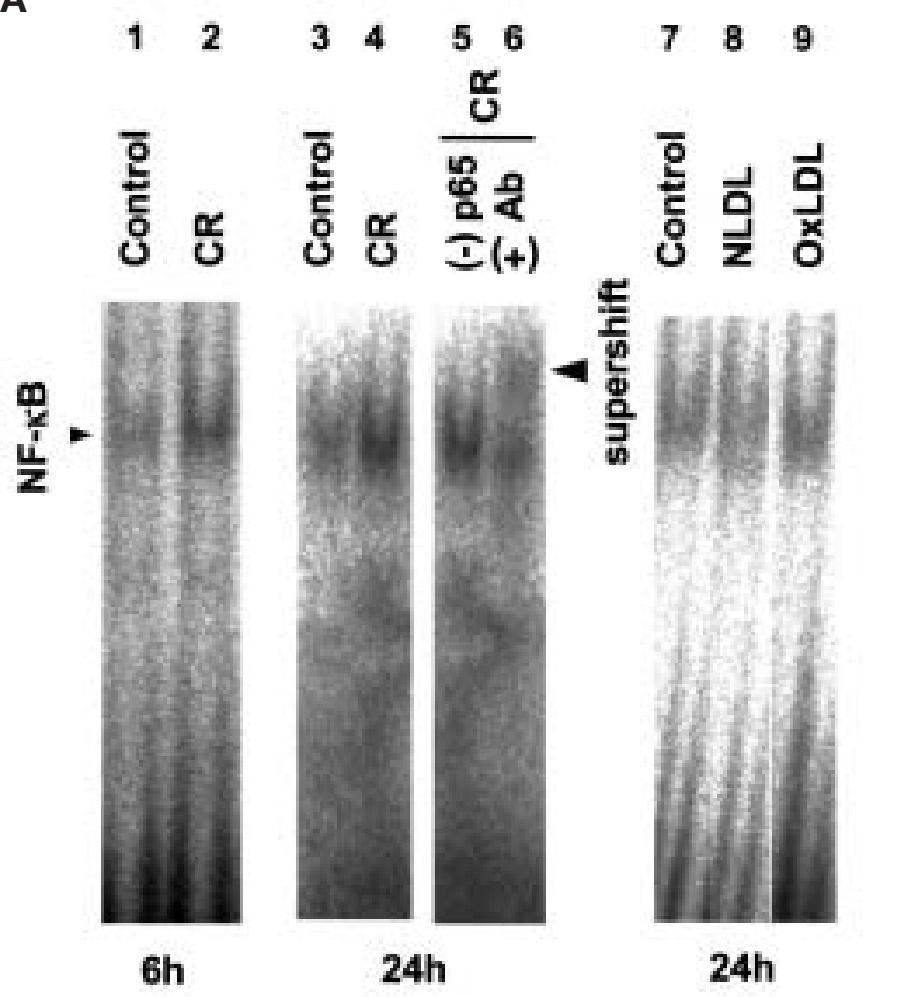

B

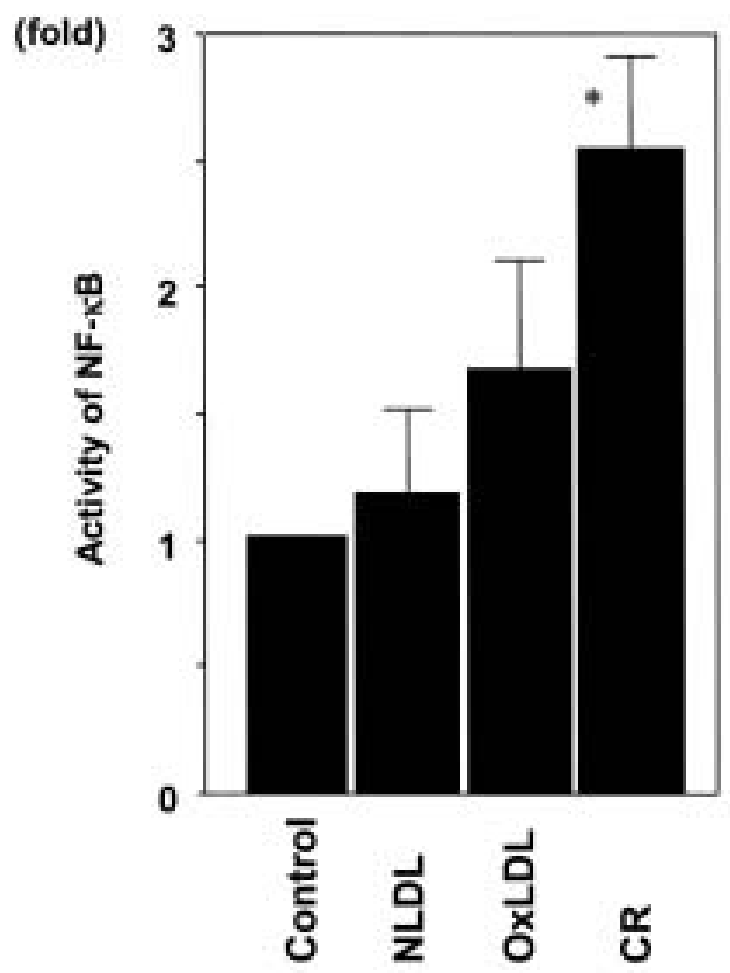

Fig. 5. A: Effects of NLDL, OxLDL, and CR on NF-kB activation. Cells were stimulated with no lipoprotein (control) or indicated lipoproteins in RPMI-1640 medium without FBS for the periods indicated. Nuclear extracts were prepared and tested for DNA binding activity of NF- $\mathrm{KB}$ with a consensus sequence probe. Lane 1, no lipoprotein (control) for $6 \mathrm{~h}$; lane $2,1.0 \mu \mathrm{g} / \mathrm{ml} \mathrm{CR}$ for $6 \mathrm{~h}$; lane 3, no lipoprotein (control) for $24 \mathrm{~h}$; lane 4, $1.0 \mu \mathrm{g} / \mathrm{ml} \mathrm{CR}$ for $24 \mathrm{~h}$; lane 5, $1.0 \mu \mathrm{g} / \mathrm{ml} \mathrm{CR}$ for 24 h without antibodies to p65 for 24 h; lane $6,1.0 \mu \mathrm{g} / \mathrm{ml} \mathrm{CR}$ for $24 \mathrm{~h}$ with antibodies to p65 for $24 \mathrm{~h}$; lane 7, no lipoprotein (control) for $24 \mathrm{~h}$; lane $8,100 \mu \mathrm{g} / \mathrm{ml} \mathrm{NLDL} \mathrm{for}$ $24 \mathrm{~h}$; lane $9,100 \mu \mathrm{g} / \mathrm{ml}$ OxLDL for $24 \mathrm{~h}$. The arrow indicates the position of NF- $\mathrm{KB}$-specific complexes. B: Densities of bands corresponding to NF- $\mathrm{KB}$ were measured by an image analyzer. The results (the mean $\pm \mathrm{SEM}$ for four independent experiments) are expressed as a percentage relative to the value obtained with the control. *, $p<0.01$ by ANOVA with Scheffé's test. 
as an independent risk factor $(3,4,13,14)$. In fact, a recent report has demonstrated that high levels of remnant-like lipoprotein particles (RLP) predict coronary events in patients with coronary artery disease, independent of traditional coronary risk factors (29). However, the cellular mechanisms that underlie the association of hypertriglyceridemia and atherosclerosis remain largely unknown. We have demonstrated that chylomicron remnants induced foam cell formation from macrophages (5), apoptosis (6) and plasminogen activator inhibitor-1 secretion (7) in endothelial cells, and monocyte chemoattractant protein-1 secretion (8) and early growth response factor-1 expression (9) in vascular smooth muscle cells. Other groups have demonstrated that RLP induced smooth muscle cell proliferation (10) and adhesion molecule expression in endothelial cells (11). These data suggest that remnants may play a critical role in atherogenesis.

The cytokines produced by macrophages in atherosclerotic lesions are thought to be important in the initiation and amplification of inflammation. IL-1 $\beta$ has been demonstrated in atherosclerotic lesions (30). IL-1 $\beta$ can alter endothelial cell function (31), enhance vascular smooth muscle cell mitogenesis (32), and recruit leukocytes to the subendothelial space (33). In this study, we showed that chylomicron remnants stimulated IL-1 $\beta$ mRNA expression and IL-1 $\beta$ release by THP-1 cells in a dose- and time-dependent manner and that chylomicron remnants activated caspase -1 and the transcription factor NF- $\kappa B$. Because mature IL-1 $\beta$ is produced from larger precursors by caspase-1 $(16,17)$, and $N F-\kappa B$ is involved in the regulation of a variety of genes including IL-1 1 , chylomicron remnants may stimulate IL-1 $\beta$ mRNA expression and IL-1 $\beta$ protein production via caspase- 1 and NF- $\kappa B$ activation in THP-1 cells. Thus, chylomicron remnants contribute to lesion formation not only by lipid supplementation but also by activation of inflammation.

Recent reports have demonstrated that IL-18 also may participate in atherogenesis in animal models and humans (20-23). IL-18 is recognized as a cytokine with varied activities ranging from T-lymphocyte helper type 1 (Th 1) polarization of the immune response to proinflammatory activity $(18,19)$. As mature IL-18 is also produced from larger precursors by caspase- 1 and NF$\kappa \mathrm{B}$ is thought to be also involved in the up-regulation of IL-18 gene expression $(15,19)$, we examined the expression of IL-18 mRNA after stimulation by native LDL, OxLDL, or chylomicron remnants in THP-1 cells, which can express IL-18 (34). However, these lipoproteins did not up-regulate IL-18 mRNA. These results suggest that additional factors are likely to regulate expression of IL$1 \beta$ and IL-18 in atherosclerotic lesions. For instance, Tsutsui et al. (35) demonstrated caspase-1-independent, Fas/Fas ligand-mediated IL-18 secretion by macrophages.
Recent findings have implicated oxidative processes in atherosclerosis. Several reports demonstrated that OxLDL modulated expression of several cytokines, although findings have varied $(26,36-38)$. Fong et al. (26) found that native LDL did not affect IL-1 $\beta$ mRNA expression in mouse peritoneal macrophages, while OxLDL inhibited expression. Ohlsson et al. (36) showed that OxLDL did not induce binding of NF- $\mathrm{KB}$ or activate the protein and that LPS-induced TNF- $\alpha$ and IL-1 $\beta$ mRNA and protein expression were decreased in macrophages incubated with OxLDL. On the other hand, Janabi et al. (37) demonstrated that OxLDL stimulated TNF- $\alpha$ and IL-1 $\beta$ secretion by human monocyte-derived macrophages. In our study, we found no significant effect of OxLDL on IL$1 \beta$ in THP-1 cells. These discrepancies are likely to involve differences in techniques used for oxidative modification, the lipid and phospholipid composition of OxLDL, and the cell lines studied. Oxidation of lipoproteins produces the formation of highly reactive molecules including lipid peroxides, aldehydes, oxysterols, LPC, and other degradation products of phospholipids (38). In particular, LPC has potent biologic effects involving the regulation of adhesion molecules and cytokines including IL$1 \beta$ (39). Importantly, the chylomicron remnants used in this study were prepared freshly for each experiment, so they did not undergo oxidative modification such as the formation of OxLDL. On the other hand, chylomicron remnants contain LPC as a result of hydrolysis $(7-9,25)$. Thus, LPC may have contributed to the stimulation of IL-1 $\beta$ production by chylomicron remnants, as opposed to the case of OxLDL. Although we have conducted no detailed analysis of the composition of lipids including fatty acids, apolipoproteins, phospholipids, and other molecule(s) in chylomicron remnants used in this study to test for the regulation of IL-1 $\beta$ production, further investigation to determine the composition of lipoprotein will be needed. Moreover, a method of measuring the serum apoB-48 concentration was recently established $(40,41)$. These methods will help us to understand clinically the importance of chylomicron remnants in atherosclerotic patients.

In summary, chylomicron remnants stimulated IL-1 $\beta$ mRNA expression and IL-1 $\beta$ protein production probably via caspase- 1 and NF- $\kappa B$ activation in THP-1 cells.

\section{References}

(1) Ross R: Atherosclerosis. An inflammatory disease. New Engl J Med, 340: 115-126, 1999

( 2 ) Libby P: Inflammation in atherosclerosis. Nature, 420: 868-874, 2002

( 3 ) Karpe F and Hamsten A: Postprandial lipoprotein metabolism and atherosclerosis. Curr Opin Lipidol, 6: 123-129, 1995

( 4 ) Yu KC and Cooper AD: Postprandial lipoproteins and atherosclerosis. Front Biosci, 6: D332-D354, 
2001

( 5 ) Fujioka Y, Cooper AD, and Fong LG: Multiple processes are involved in the uptake of chylomicron remnants by mouse peritoneal macrophages. J Lipid Res, 139: 2339-2349, 1998

( 6 ) Kawasaki S, Taniguchi T, Fujioka Y, Takahashi A, Takahashi T, Domoto K, Taguchi M, Ishikawa Y, and Yokoyama M: Chylomicron remnant induced apoptosis in vascular endothelial cells. Ann NY Acad Sci, 902: 336-341, 2000

( 7 ) Morimoto S, Fujioka Y, Hosoai H, Okumura T, Masai M, Sakoda T, Tsujino T, Ohyanagi M, and Iwasaki $\mathrm{T}$ : The renin-angiotensin system is involved in the production of plasminogen activator inhibitor type 1 by cultured endothelial cells in response to chylomicron remnants. Hypertens Res, 26: 315-323, 2003

( 8 ) Domoto K, Taniguchi T, Takaishi H, Takahashi T, Fujioka Y, Takahashi A, Ishikawa Y, and Yokoyama $M$ : Chylomicron remnants induce monocyte chemoattractant protein-1 expression via p38 MAPK activation in vascular smooth muscle cells. Atherosclerosis, 171: 193-200, 2003

( 9 ) Takahashi Y, Fujioka Y, Takahashi T, Domoto K, Takahashi A, Taniguchi T, Ishikawa $Y$, and Yokoyama M: Chylomicron remnants regulate early growth response factor-1 in vascular smooth muscle cells. Life Sci, 77: 670-682, 2005

(10) Kawakami A, Tanaka A, Chiba T, Nakajima K, Shimokado K, and Yoshida M: Remnant lipoprotein-induced smooth muscle cell proliferation involves epidermal growth factor receptor transactivation. Circulation, 108: 2679-2688, 2003

(11) Doi H, Kugiyama K, Oka H, Sugiyama S, Ogata N, Koide SI, Nakamura SI, and Yasue H: Remnant lipoproteins induce proatherothrombogenic molecules in endothelial cells through a redox-sensitive mechanism. Circulation, 102: 670-676, 2000

(12) Kawakami A and Yoshida M: Remant lipoproteins and atherosclerosis. J Atheroscler Thromb, 12: 7376, 2005

(13) Wilhelm MG and Cooper AD: Induction of atherosclerosis by human chylomicron remnants: A hypothesis. J Atheroscler Thromb, 10: 132-139, 2003

(14) Tanaka A: Postprandial hyperlipidemia and atherosclerosis. J Atheroscler Thromb, 11: 322-329, 2004

(15) Hazuda D, Webb RL, Simon P, and Young P: Purification and characterization of human recombinant precursor interleukin 1 beta. J Biol Chem, 264: 1689-1693, 1989

(16) Kostura MJ, Tocci MJ, Limjuco G, Chin J, Cameron P, Hillman AG, Chartrain NA, and Schmidt JA: Identification of a monocyte specific pre-interleukin 1 beta convertase activity. Proc Natl Acad Sci U S A, 86: 5227-5231, 1989
(17) Cerretti DP, Kozlosky CJ, Mosley B, Nelson N, Van Ness K, Greenstreet TA, March CJ, Kronheim SR, Druck T, Cannizzaro LA, Huebner K, and Black RA: Molecular cloning of the interleukin-1 beta converting enzyme. Science, 256 (5053): 97-100, 1992

(18) Okamura $H$, Tsutsui $H$, Komatsu $T$, Yutsudo $M$, Hakura A, Tanimoto T, Torigoe K, Okura T, Nukada Y, Hattori K, Akita K, Namba M, Tanabe F, Konishi $\mathrm{K}$, Fukuda S, and Kurimoto M: Cloning of a new cytokine that induces IFN- $\gamma$ production by T cells. Nature, 378: 88-91, 1995

(19) Nakanishi K, Yoshimoto T, Tsutsui $\mathrm{H}$, and Okamura $\mathrm{H}$ : Interleukin-18 regulates both Th1 and Th2 responses. Annu Rev Immunol, 19: 423-474, 2001

(20) Mallat Z, Corbaz A, Scoazec A, Besnard S, Leseche G, Chvatchko Y, and Tedgui A: Expression of interleukin-18 in human atherosclerotic plaques and relation to plaque instability. Circulation, 104: 15981603, 2001

(21) Whitman SC, Ravisankar P, and Daugherty A: Interleukin-18 enhances atherosclerosis in apolipoprotein $\mathrm{E}(-/-)$ mice through release of interferon-gamma. Circ Res, 90: E34-E38, 2002

(22) Gerdes N, Sukhova GK, Libby P, Reynolds RS, Young JL, and Schonbeck U: Expression of interleukin (IL)-18 and functional IL-18 receptor on human vascular endothelial cells, smooth muscle cells, and macrophages: implications for atherogenesis. J Exp Med, 195: 245-257, 2002

(23) Elhage R, Jawien J, Rudling $M$, Ljunggren $H-G$, Takeda K, Akira S, Bayard F, and Hansson GK: Reduced atherosclerosis in interleukin-18 deficient apolipoprotein E-knockout mice. Cardiovasc Res, 59: 234-240, 2003

(24) Ellsworth JL, Cooper AD, and Kraemer FB: Evidence that chylomicron remnants and $\beta$-VLDL are transported by the same receptor pathway in $\mathrm{J} 774 \mathrm{mu}-$ rine macrophage-derived cells. J Lipid Res, 27: 1062-1072, 1986

(25) Scow RO and Egelrud T: Hydrolysis of chylomicron phosphatidylcholine in vitro by lipoprotein lipase, phospholipase A2 and phospholipase C. Biochim Biophys Acta, 431: 538-549, 1976

(26) Fong LG, Fong TAT, and Cooper AD: Inhibition of lipopolysaccharide-induced interleukin- $1 \beta$ mRNA expression in mouse macrophages by oxidized low density lipoprotein. J Lipid Res, 32: 1899-1910, 1991

(27) Kalina U, Koyama N, Hosoda T, Nuernberger H, Sato K, Hoelzer D, Herweck F, Manigold T, Singer MV, Rossol S, and Bocker U: Enhanced production of IL-18 in butyrate-treated intestinal epithelium by stimulation of the proximal promoter region. Eur $\mathrm{J}$ Immunol, 32: 2635-2643, 2002

(28) Lowry OH, Rosenbrough NJ, Farr AL, and Randall 
RJ: Protein measurement with the Folin phenol reagent. J Biol Chem, 193: 265-275, 1951

(29) Kugiyama K, Doi H, Takazoe K, Kawano H, Soejima H, Mizuno Y, Tsunoda R, Sakamoto T, Nakano T, Nakajima K, Ogawa H, Sugiyama S, Yoshimura M, and Yasue H: Remnant lipoprotein levels in fasting serum predict coronary events in patients with coronary artery disease. Circulation, 99: 2858-2860, 1999

(30) Tipping PG and Hancock WW: Production of tumor necrosis factor and interleukin-1 by macrophages from human atheromatous plaques. Am J Pathol, 142: 1721-1728, 1993

(31) Bevilacqua MP, Pober JS, Majeau GR, Fiess W, Cotran RS, and Gimbrone MAJ: Recombinant tumor necrosis factor induces procoagulant activity in cultures human vascular endothelium: Characterization and comparison with the actions of interleukin 1. Proc Natl Acad Sci USA, 83: 45374542, 1986

(32) Libby P, Wyler DJ, Janicka MW, and Dinarello CA: Differential effects of human interleukin-1 on growth of fibroblasts and vascular smooth muscle cells. Arteriosclerosis, 5: 186-191, 1985

(33) Bevilacqua MP, Pober JS, Wheeler ME, Cotran RS, and Gimbrone MAJ: Interleukin 1 acts on cultured human vascular endothelium to increase the adhesion of polymorphonuclear leukocytes, monocytes, and related leukocyte cell lines. J Clin Invest, 76: 2003-2011, 1985

(34) Akita K, Ohtsuki T, Nukada Y, Tanimoto T, Namba M, Okura T, Takakura-Yamamoto R, Torigoe K, Gu Y, Su MS, Fujii M, Satoh-Itoh M, Yamamoto K, Kohno K, Ikeda M, and Kurimoto M: Involvement of caspase- 1 and caspase- 3 in the production and processing of mature human interleukin 18 in monocytic THP. 1 cells. J Biol Chem, 272: 26595-26603, 1997

(35) Tsutsui H, Kayagaki N, Kuida K, Nakano H, Hayashi
N, Takeda K, Matsui K, Kashiwamura S, Hada T, Akira S, Yagita H, Okamura H, and Nakanishi K: Caspase-1-independent, Fas/Fas ligand-mediated IL-18 secretion from macrophages causes acute liver injury in mice. Immunity, 11: 359-367, 1999

(36) Ohlsson BG, Englund MC, Karlsson AL, Knutsen E, Erixon C, Skribeck H, Liu Y, Bondjers G, and Wiklund O: Oxidized low density lipoprotein inhibits lipopolysaccharide-induced binding of nuclear factor- $1 \beta$ to DNA and the subsequent expression of tumor necrosis factor- $\alpha$ snd interleukin- $1 \beta$ in macrophages. J Clin Invest, 98: 78-89, 1996

(37) Janabi M, Yamashita S, Hirano K, Sakai N, Hiraoka $\mathrm{H}$, Matsumoto K, Zhang Z, Nozaki S, and Matsuzawa Y: Oxidized LDL-induced NF- $\mathrm{KB}$ activation and subsequent expression of proinflammatory genes are defective in monocyte-derived macrophages from CD36-deficient patients. Arterioscler Thromb Vasc Biol, 20: 1953-1960, 2000

(38) Thomas CE, Jackson RL, Ohlweiler DF, and Ku G: Multiple lipid oxidation products in low density lipoproteins induce interleukin-1 beta release from human blood mononuclear cells. J Lipid Res, 35: 417-427, 1994

(39) Liu-Wu Y, Hurt-Camejo E, and Wiklund O: Lysophosphatidylcholine induces the production of IL-1 $\beta$ by human monocytes. Atherosclerosis, 137: 351-357, 1998

(40) Sakai N, Uchida Y, Ohashi K, Hibuse T, Saika Y, Tomari Y, Kihara S, Hiraoka H, Nakamura T, Ito S, Yamashita S, and Matsuzawa Y: Measurement of fasting serum apoB-48 levels in normolipidemic and hyperlipidemic subjects by ELISA. J Lipid Res, 44: 1256-1262, 2003

(41) Kinoshita M, Kojima M, Matsushima T, and Teramoto T: Determination of apolipoprotein B-48 in serum by a sandwich ELISA. Clin Chim Acta, 351 : 115-120, 2005 